\title{
FAKTOR-FAKTOR YANG MEMPENGARUHI KEBERHASILAN UMKM (STUDI KASUS PADA UMKM DI KOTA BOGOR)
}

\author{
Eka Merdekawati ${ }^{1}$, Novi Rosyanti ${ }^{2}$ \\ Vocational School, Bogor Agricultural University \\ Email: eka.merdekawati@apps.ipb.ac.id
}

\section{KETERANGAN ARTIKEL}

Riwayat Artikel

Diterima: 10 November 2019

Direvisi: 15 November 2019

Disetujui: 1 Desember 2019

Klasifikasi JEL

M14, M41

\section{Keywords: $\quad$ Accounting \\ Understanding, Marketing Strategy, UMKM Success}

Kata Kunci: Pemahaman

Akuntansi, Strategi

Pemasaran, Keberhasilan

UMKM.

\section{ABSTRACT}

SMEs in the city of Bogor need to be developed because the existence of MSMEs can help increase economic growth and increase regional income. The purpose of this study is to analyze that accounting understanding and marketing strategies are factors that influence the success of MSMEs in Bogor City. The sampling technique used in this study is convenience sampling method. The sample used in this study were 41 SME owners located in Central Bogor City. The analysis technique used is the analysis of the Mutivariat dependencies using multiple regression. The results showed that Accounting Understanding influences the Success of MSMEs in Bogor City with the conclusion that H1 was accepted. While the marketing strategy has no effect on the success of SMEs in the city of Bogor with the conclusion $\mathrm{H} 2$ is rejected. This implies that in the future the UMKM party will increase the understanding of accounting to support the UMMM success.

\section{ABSTRAK}

UMKM di Kota Bogor perlu untuk dikembangkan karena keberadaan UMKM dapat membantu meningkatkan pertumbuhan ekonomi dan menambah pendapatan daerah. Tujuan dari penelitian ini adalah untuk menganalis bahwa pemahaman akuntansi dan strategi pemasaran merupakan faktor-faktor yang mempengaruhi Keberhasilan UMKM di Kota Bogor. Teknik pengambilan sampel yang digunakan dalam penelitian ini adalah metode convenience sampling. Sampel yang digunakan dalam penelitian ini sebanyak 41 orang pemilik UMKM yang berlokasi di Kota Bogor Tengah. Teknik analisis yang digunakan adalah dengan analisis Mutivariat dependensi dengan menggunakan regresi berganda. Hasil penelitian menunjukan bahwa Pemahaman Akuntansi berpengaruh terhadap Keberhasilan UMKM di Kota Bogor dengan kesimpulan $\mathrm{H}_{1}$ diterima. Sedangkan Strategi pemasaran tidak berpengaruh terhadap Keberhasilan UMKM di Kota Bogor dengan kesimpulan $\mathrm{H}_{2}$ ditolak. Hal ini mengandung implikasi agar ke depannya pihak UMKM meningkatkan pemahaman akuntansi untuk menopang keberhasilan UMKM.

\section{PENDAHULUAN}

Usaha Mikro Kecil Menengah atau yang disebut UMKM merupakan salah satu bagian penting dari perekonomian suatu negara maupun daerah, begitu pula yang terjadi di Indonesia. UMKM memiliki peranan yang 
sangat penting bagi perekonomian bangsa, seperti pertumbuhan ekonomi, pengurangan kemiskinan, demokratisasi ekonomi, penciptaan lapangan kerja, penguatan struktur ekonomi lokal, serta serangkaian sasaransasaran social dalam pembangunan nasional. Sektor industri UMKM diyakini sebagai sektor yang dapat memimpin sektor lain dalam sebuah perekonomian menuju kemajuan. Pemberdayaan Usaha Mikro Kecil dan Menengah (UMKM) merupakan langkah yang strategis dalam meningkatkan dan memperkuat dasar kehidupan perekonomian dari sebagaian besar rakyat Indonesia, khususnya melalui penyediaan lapangan kerja dan mengurangi kesenjangan tingkat kemiskinan.

Data Usaha Kecil dan Menengah dikumpulkan melalui survey terintegrasi Usaha Kecil dan Menengah oleh BPS (Badan Pusat Statistik), yang merupakan survey kelanjutan dari sensus ekonomi yang hanya memfokuskan pada perusahaan tanpa identitas resmi. Berdasarkan survey BPS tersebut tahun 2016 potensi UMKM antara lain dapat dilihat dari jumlah pelaku usahanya yang relatif banyak, kemampuannya menunjang kegiatan kepariwisataan dan juga kontribusi penyerapan yang besar terhadap tenaga kerja di Kota Bogor. Menurut Kementrian Koperasi dan UKM, di Indonesia hingga tahun 2016 terdapat sekitar 57,9 juta pelaku UMKM dengan memberi kontribusi terhadap PDB 58,92\% dan penyerapan tenaga kerja 97,30\%, sedangkan menurut BPS menyatakan pada tahun 2016 jumlah UKM yang berada di Kota Bogor yaitu sekitar 32.901 UMKM.

Kepala Dinas Koperasi dan UMKM Kota Bogor, Jawa Barat, Annas S Rasmana dalam acara Forum Diskusi Terarah (FGD) dan pertemuan usaha penguatan kelembagaan inkubator bisnis teknologi Kemenristekdikti 2017 di Kota Bogor menyebutkan jumlah UKM di kota tersebut cukup dinamis dibanding nasional tercatat ada 23 ribu usaha kecil menengah (UKM), namun dari 23 ribu itu yang aktif hanya delapan ribu, sedangkan sisanya sekitar 15 ribuan hanya menunggu momen pameran, bazar atau hari-hari tertentu saat menerima orderan. Untuk itu, peran lembaga inkubator seperti Pusat Inkubator Bisnis dan Pengembangan Kewirausahaan LPPM IPB sangat dibutuhkan untuk membantu pengembangan UKM di Kota Bogor." Keberadaan UKM dan koperasi tersebut membuat pertumbuhan ekonomi di Kota Bogor lebih tinggi di banding nasional yakni 6,7 persen, sementara nasional hanya 5,1 persen" (Syarif, 2017).

Keberhasilan usaha sendiri dapat ditandai dengan peningkatan jumlah penjualan, meningkatnya jumlah produksi, meningkatnya keuntungan atau laba serta usaha yang selalu berkembang (Arlianto, 2014). Untuk mencapai keberhasilan tersebut tidak terlepas dari kerja keras para individu yang ada di dalamnya. Kebijakan-kebijakan dan pengambilan keputusan manajerial yang tepat merupakan kunci keberhasilan UMKM.

Pemahaman akuntansi merupakan salah satu faktor yang dapat mempengaruhi keberhasilan UMKM. Hasil penelitian Arlianto (2014) menyatakan bahwa informasi akuntansi memegang kunci peranan yang penting bagi keberhasilan usaha kecil dan menengah dalam rangka pengambilan keputusan yang bersifat keuangan. Hasil yang serupa juga ditunjukkan oleh penelitian yang dilakukan oleh (AL Smirat, 2013) yang menyatakan bahwa praktik akuntansi yang baik berpengaruh positif terhadap keberhasilan UMKM. Penelitian lain juga dilakukan oleh Rini (2016) bahwa terdapat pengaruh yang signifikan antara pengalaman usaha terhadap keberhasilan usaha yang dimediasi oleh pemahaman informasi akuntansi.

Warcito \& Saleh (2016) mengemukakan bahwa strategi alternatif untuk pengembangan usaha mikro dan kecil pada usaha pengolahan pangan merupakan strategi intensif atau pertumbuhan yang agresif (Growth Oriented Strategy) dengan menggunakan kekuatan untuk memanfaatkan 
peluangnya, melalui pengembangan pasarpasar mikro dan kecil di wilayah Bogor. Sedangkan Sara (2014), usaha-usaha pemasaran adalah suatu sistem keseluruhan dari kegiatan bisnis yang dirancang untuk merencanakan, menentukan harga, mempromosikan dan mendistribusikan barang yang dapat memuaskan keinginan dan kebutuhan baik kepada konsumen saat ini maupun konsumen potensial. Penelitian lain yang oleh Nandita et al. (2018) pemasaran kewirausahaan berpengaruh signifikan positif terhadap keberhasilan usaha. Berdasarkan observasi dan wawancara, pelaku usaha melakukan pemasaran produk dengan cara memanfaatkan jaringan dengan sesama pelaku usaha, informasi dari mulut ke mulut, dan menyesuaikan selera pasar. Sedangkan menurut Yasri dan Muchtar (2014) menunjukan bahwa strategi pemasaran mempunyai pengaruh yang signifikan terhadap perkembangan UMKM

Berdasarkan uraian diatas dapat disimpulkan bahwa pemahaman akuntansi dan strategi pemasaran merupakan beberapa faktor yang dapat menentukan keberhasilan UMKM termasuk UMKM di Bogor yang masih perlu pengembangan seperti yang di katakan oleh Kepala Dinas Koperasi dan UMKM kota Bogor dalam Forum group discussion diatas. Dengan demikian dalam penelitian ini penulis akan memelakukan penelitian dengan judul Pengaruh Pemahaman Akuntansi dan strategi pemasaran terhadap Keberhasilan UMKM (Studi Kasus Pada UMKM di Kota Bogor Tengah). Adapun tujuan penelitian ini adalah untuk menganalis bahwa pemahan akuntansi dan strategi pemasaran merupakan faktorfaktor yang mempengaruhi Keberhasilan UMKM di Kota Bogor.

\section{KAJIAN LITERATUR DAN PENGEMBANGAN HIPOTESIS}

UMKM adalah peluang usaha produktif milik orang perorangan atau badan usaha perorangan yang memenuhi kriteria usaha mikro sebagaimana diatur oleh undangundang. Usaha kecil adalah peluang usaha ekonomi produktif yang berdiri sendiri, yang dilakukan oleh orang perorangan atau badan usaha yang bukan merupakan anak perusahaan atau bukan cabang perusahaan yang dimiliki, dikuasai, atau menjadi bagian baik langsung maupun tidak langsung dari usaha menengah atau usaha besar yang memenuhi kriteria usaha kecil sebagaimana yang dimaksud dalam undang-undang.

Menurut Undang-Undang Nomor 20 Tahun 2008 pasal 1 mengenai UMKM, Usaha Mikro adalah usaha produktif milik orang perorangan dan/atau badan usaha perorangan yang memenuhi kriteria usaha mikro sebagaimana diatur dalam undang-undang Kriteria Usaha Mikro Kecil dan Menengah menurut undang- undang nomor 20 tahun 2008 pasal 6 adalah sebagai berikut: (a) Kriteria usaha mikro adalah sebagai berikut: memiliki asset maksimal Rp 50 juta, dengan omset maksimal Rp 300 juta/tahun. (b) Kriteria usaha kecil memilik asset $>$ Rp 50 JutaRp 500 juta dengan omset $>$ Rp 300 juta-2.5 $\mathrm{M} /$ tahun. (c) Kriteria usaha menengah memiliki asset $>$ Rp 500 juta-Rp $10 \mathrm{M}$ dengan Omset > Rp $2.5 \mathrm{M}-\mathrm{Rp} 50 \mathrm{M} /$ Tahun. Bentuk Usaha Mikro, Kecil Dan Menengah (UMKM) berupa perusahaan perorangan, persekutuan, seperti halnya firma dan CV maupun perseroan terbatas.

\section{Pengaruh Pemahaman Akuntansi terhadap Keberhasilan Usaha}

Wibowo \& Kurniawati (2016) penggunaan informasi akuntansi yang salah satunya adalah pemahaman akuntansi terbukti berpengaruh secara positif terhadap keberhasilan usaha pada UKM sentra konveksi di Kecamatan Tingkir Salatiga. Lohanda (2017) menunjukkan bahwa terdapat pengaruh positif pemahaman akuntansi terhadap pelaporan keuangan berdasarkan SAK ETAP pada UMKM Kerajinan Batik Kecamatan Kraton Yogyakarta. Penelitian mengenai 
pemahaman akuntansi pernah dilakukan oleh Wilfa, Razannisa; Sagoro (2016) yang menyatakan bahwa pemahaman akuntansi berpengaruh positif dan signifikan terhadap kualitas laporan keuangan. Penelitian lain juga dilakukan oleh Rini (2016) yang menggunakan sampel 100 pelaku usaha mikro kecil dan menengah yang berusia muda di Kabupaten Sidoarjo. Hasil penelitiannya menunjukkan bahwa terdapat pengaruh yang signifikan antara pengalaman usaha terhadap keberhasilan usaha yang dimediasi oleh pemahaman informasi akuntansi. Berdasarkan pemahaman diatas, maka dapat disimpulkan hipotesis penelitian sebagai berikut:

$\mathrm{H}_{1}$ : Pemahaman akuntansi berpengaruh terhadap keberhasilan usaha

\section{Pengaruh Strategi Pemasaran terhadap Keberhasilan Usaha}

Nursalina (2018) merek promosi berpengaruh terhadap keberhasilan usha mikro kecil berbasis ekonomi kreatif di kota Makassar. Merk promosi merupakan bagian dari strategi pemasaran. Sedangkan Saragi (2016) dalam penelitiannya menjelaskan bahwa unsur-unsur utama pemasaran dapat diklasifikasikan menjadi tiga unsur utama yaitu strategi persaingan, taktik pasar dan nilai pemasaran. Strategi persaingan dikelompokan menjadi tiga, yaitu: 1) Segmentasi pasar adalah tindakan mengidentifikasi dan membentuk kelompok pembeli atau konsumen secara terpisah; 2) targeting adalah suatu tindakan memilih satu atau lebih segmen pasar yang akan dimasuki; dan 3) positioning adalah penetapan posisi pasar.
Nandita et al. (2018) pemasaran kewirausahaan berpengaruh signifikan positif terhadap keberhasilan usaha. Berdasarkan observasi dan wawancara, pelaku usaha melakukan pemasaran produk dengan cara memanfaatkan jaringan dengan sesama pelaku usaha, informasi dari mulut ke mulut, dan menyesuaikan selera pasar. Sara (2014) usaha-usaha pemasaran adalah suatu system keseluruhan dari kegiatan bisnis yang dirancang untuk merencanakan, menentukan harga, mempromosikan dan mendistribusikan barang yang dapat memuaskan keinginan dan kebutuhan baik kepada konsumen saat ini maupun konsumen potensial. Berdasarkan penelitian Sitohang (2011) menunjukkan bahwa faktor modal, ketrampilan, mesin dan peralatan produksi, kemitraan, tenaga kerja dan pendidikan secara bersama-sama (uji-F) berpengaruh secara signifikan terhadap keberhasilan usaha industri kecil. Berdasarkan pemahaman diatas, maka dapat disimpulkan hipotesis penelitian sebagai berikut:

$\mathrm{H}_{2}$ : Strategi pemasaran berpengaruh terhadap Keberhasilan usaha

Berikut kerangka pemikiran dalam penelitian ini.

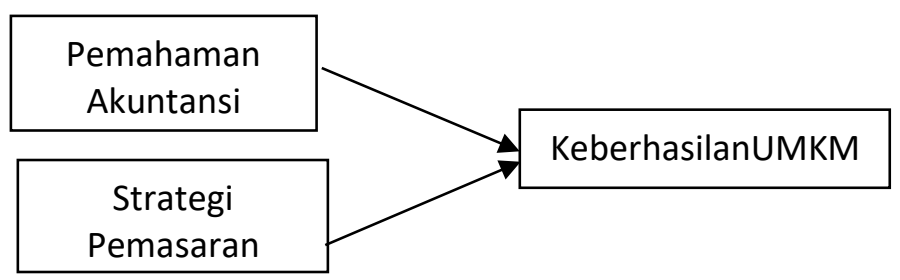

Gambar 1. Kerangka Penelitian

Sumber: Peneliti (2018)

Operasionalisasi Variabel 
Tabel 1. Operasionalisasi Variabel

\begin{tabular}{|c|c|c|c|}
\hline $\begin{array}{l}\text { Nama } \\
\text { Variabel }\end{array}$ & Definisi Variabel & Indikator & Sumber \\
\hline $\begin{array}{l}\text { Pemahaman } \\
\text { Akuntansi (X1) }\end{array}$ & $\begin{array}{l}\text { Proses, cara perbuatan } \\
\text { memahami atau memahamkan. } \\
\text { Ini berarti dapat disimpulkan } \\
\text { bahwa orang yang memiliki } \\
\text { pemahaman akuntansi adalah } \\
\text { orang yang pandai dan mengerti } \\
\text { benar tentang akuntansi }\end{array}$ & $\begin{array}{l}\text { Pandai dalam menyelesaikan } \\
\text { siklus akuntansi dari mulai } \\
\text { pencatatan Jurnal hingga } \\
\text { pembuatan laporan Keuangan }\end{array}$ & $\begin{array}{l}\text { (Wilfa, } \\
\text { Razannisa; } \\
\text { Sagoro, } \\
\text { 2016) }\end{array}$ \\
\hline $\begin{array}{l}\text { Strategi } \\
\text { Pemasaran } \\
(\mathrm{X} 2)\end{array}$ & $\begin{array}{l}\text { Proses kegiatan yang dipengaruhi } \\
\text { oleh berbagai faktor social, } \\
\text { budaya, politik, ekonomi dan } \\
\text { manajerial }\end{array}$ & -Adanya segmentasi pasar & $\begin{array}{l}\text { Adhe } \\
\text { Anggreini } \\
\text { Saragi } \\
(2016)\end{array}$ \\
\hline $\begin{array}{l}\text { Keberhasilan } \\
\text { UMKM (Y) }\end{array}$ & $\begin{array}{l}\text { Suatu perusahaan dikatakan } \\
\text { berhasil jika perusahaan dapat } \\
\text { mencapai tujuan yang telah } \\
\text { ditetapkan sebelumnya }\end{array}$ & $\begin{array}{l}\text {-Pemanfaatan Modal } \\
\text {-Keterampilan } \\
\text { - Kemitraan } \\
\text {-Pendidikan } \\
\text {-bertambahnya Tenaga Kerja }\end{array}$ & $\begin{array}{l}\text { Sonang } \\
\text { Sitohan } \\
(2011)\end{array}$ \\
\hline
\end{tabular}

Sumber: Data diolah (2018)

\section{METODE PENELITIAN}

Teknik pengambilan sampel yang digunakan dalam penelitian ini adalah metode convenience sampling. Sampel yang digunakan dalam penelitian ini sebanyak 41 orang pemilik UMKM yang berlokasi di Kota Bogor Tengah. Jenis data yang digunakan adalah data kuantitatif. Data kuantitatif adalah data berbentuk angka atau data kualitatif yang diangkakan (Scoring). Unit analisis dalam penelitian ini adalah individu dalam UMKM, karena peneliti mengambil data dari setiap individu yang dijadikan sebagai sumber data, Dimana saja dan bagaimana sampelnya. Sumber data yang digunakan dalam penelitian ini adalah data primer. Teknik Pengumpulan data yang digunakan dalam penelitian ini adalah dengan menggunakan Kuisoner. Dalam penelitian ini, digunakan kuisoner tertutup dengan Teknik pengukuran yang digunakan adalah Likert's Summated Rating (LSR) yaitu untuk mengukur sikap, pendapat, persepsi seseorang atau sekelompok orang tentang fenomena tertentu yang ingin diketahui (BPAM, 2008). Agar peneliti dapat dengan sungguh-sungguh atau asal-asalan, sebaiknya angket disusun berdasarkan pernyataan positif dan pernyataan negatif. Untuk pernyataan positif, penskoran jawaban biasanya sebagai berikut: $\mathrm{STS}=1, \mathrm{TS}=2, \mathrm{~S}=3, \mathrm{SS}=4$, dan $\mathrm{TM}=5$. Sedangkan untuk pernyataan negatif sebaliknya.

\section{Analisis Data}

Dalam penelitian ini teknik analisis yang digunakan adalah dengan analisis Mutivariat dependensi dengan menggunakan regresi berganda. Analisis regresi berganda memiliki kegunaan untuk meramalkan nilai variabel terikat $(Y)$ apabila variabel bebasnya $(X)$ dua atau lebih (Augustine dan Kristaung, 2013). Analisis regresi berganda bertujuan untuk membuktikan ada atau tidaknya hubungan fungsional atau hubungan kausal antara dua atau lebih variabel bebas $X 1, X 2, \ldots, X i$ terhadap suatu variabel terikat $Y$. Persamaan regresi berganda yang digunakan dalam penelitian ini adalah yang memiliki tiga variabel bebas, yaitu: 
$Y=a+b 1 X 1+b 2 X 2+e$

Keterangan:

Y : Keberhasilan UMKM

a : Konstansta $Y$

b : : Koefisien arah regresi/

X1 : Pemahaman mengenai Akuntansi dan keuangan

X2 : Strategi Pemasaran

e : Unsur residual yang merupakan gangguan untuk sampel

\section{HASIL DAN PEMBAHASAN}

Hasil Uji Validitas, Reliabilitas, dan Uji Asumsi Klasik

Ghozali (2011) suatu konstruk atau variabel dikatakan valid dan reliabel jika memberikan nilai Cronbach Alpha $>0,6$. Semua item pertanyaan kuesioner untuk variabel pemahaman akuntansi, strategi pemasaran, dan keberhasilan UMKM adalah valid dan reliable. Hasil Uji multikolinieritas untuk seluruh variabel dalam model persamaan memiliki VIF $<10$. Dengan demikian dapat disimpulkan bahwa seluruh variabel independen tersebut tidak memiliki masalah multikolinieritas untuk semua model persamaan.

Uji Autokorelasi menyatakan nilai Durbin Watson sebesar 1,494. Nilai dL dan dU yaitu 1,3992 dan 1,6031 maka nilai autokorelasi diantara 1,6031 >1,494 $<2,3969$ sehingga terjadi autokorelasi dalam model persamaan. Uji normalitas menggunakan $\mathrm{Uji}$ Kolmogorov-Smirnov dengan nilai data residual memilii nilai signifikansi sebesar 0,858 $>0,05$ sehingga dapat disimpulkan bahwa data residual berdistri normal, yang berarti bahwa model regresi memiliki nilai yang berdistribusi normal.

Hasil Uji heteroskedastisitas dengan menggunakan scatterplot, hasil pengujian tidak membentuk pola tertentu sehingga dapat disimpulkan bahwa model dalam penelitian ini memenuhi syarat karena asumsi linieritasnya pterpenuhi.

\section{Hasil Uji Hipotesis}

\section{Koefisien Regresi Berganda}

Pengaruh variabel Pemahaman Akuntansi dan Strategi Pemasaran terhadap Kelangsungan Usaha UMKM dianalisis menggunakan SPSS ver. 19.0. Analisis regresi berganda digunakan untuk mengetahui seberapa besar pengaruh variabel bebas yaitu Pemahaman Akuntansi (X1), Strategi Pemasaran (X2), terhadap variabel terikat yaitu Keberhasilan UMKM (Y1). Hasilnya dapat berupa tanda negatif atau positif terhadap Kelangsungan Usaha UMKM. Hasil analisis regresi berganda menggunakan program SPSS ver 19 disajikan dalam tabel berikut:

Tabel 2. Koefisien Regresi Linier Berganda

Variabel Dependent:

Keberhasilan UMKM

\begin{tabular}{llll}
\hline $\begin{array}{l}\text { Variabel } \\
\text { Independent }\end{array}$ & Koefisien & t-Hitung & Sig \\
\hline Konstanta & 5,084 & 3,562 & 0,001 \\
\hline Pemahaman & 0,376 & 4,246 & 0,000
\end{tabular}

Akuntansi

\begin{tabular}{llll}
\hline Strategi Pemasaran & 0,199 & 0,110 & 0,080 \\
\hline R-squared & 0,768 & & \\
\hline Adjusted R-squared & 0,568 & & \\
\hline F-stat & 27,333 & & \\
\hline F-prob & 0,000 & & \\
\hline
\end{tabular}

Sumber: Data diolah dengan SPSS 19.0 
Hasil persamaan menggunakan koefisien adalah sebagai berikut:

$$
Y=5,084+0,376 X_{1}+0,199 \times 2
$$

Interpretasi dari hasil analisis tersebut adalah sebagai berikut:

Konstanta adalah sebesar 5,084 yang berarti bahwa apabila tidak terdapat pengaruh antara variabel bebas: Pemahaman Akuntansi (X1) dan Strategi Pemasaran (X2) maka nilai Y adalah 5,084.

Nilai Koefisien regresi Pemahaman Akuntansi (X1) berpengaruh positif terhadap Keberhasilan UMKM seperti yang ditunjukan dengan adanya nilai koefisien regresi 0,376. Hasil pengujian $T$ - statistic menunjukan nilai probabilitas $T$ sebesar 0,000 atau $<0,05$ dan nilai dari t-hitung sebesar 0 , atau $>\mathrm{t}$ - tabel 1,68. Dengan demikian hasil model di atas dapat diintepretasikan bahwa apabila setiap kenaikan satu satuan dari variabel Pemahaman Akuntansi maka variabel Keberhasilan Usaha UMKM akan meningkat sebesar 0,376.

Nilai Koefisien regresi Strategi Pemasaran (X2) berpengaruh positif terhadap Keberhasilan UMKM seperti yang ditunjukan dengan adanya nilai koefisien regresi 0,199. Hasil pengujian $\mathrm{T}$ - statistic menunjukan nilai probabilitas $T$ sebesar 0,080 atau $>0,05$ dan nilai dari t-hitung adalah 0,110 atau $<$ dari ttabel 1,68. Dengan demikian hasil model di atas dapat diintepretasikan bahwa dalam penelitian ini variabel Strategi Pemasaran tidak berpengaruh signifikan terhadap variabel Keberhasilan Usaha UMKM.

Koefisien korelasi simultan dapat dlakukan dengan mencari persamaan regresinya, yaitu dengan melihat uji $F$. Berdasarkan hasil pengujian menunjukan bahwa nilai $F$ prob 0,000 yaitu $<0,05$ dan $F$ stat adalah 27,333 yaitu > dari 3,24 yang mengartikan bahwa variabel independen yaitu (Pemahaman Akuntansi dan Strategi Pemasaran) secara simultan atau secara bersama-sama berpengaruh terhadap variabel dependen (Keberhasilan UMKM).

Secara keseluruhan, hasil analisis regresi di atas menunjukan bahwa variabel Pemahaman Akuntansi (X1) berpengaruh secara positif kepada variabel Keberhasilan UMKM $(Y)$, sedangkan variabel Strategi Pemasaran (X2) berpengaruh negative kepada Keberhasilan UMKM (Y). Dan dilihat dari kedua variabel bebas yang digunakan, variabel Pemahaman Akuntansi (X1) memiliki pengaruh yang paling besar.

\section{Hasil Uji Koefisien Determinasi (Uji $\mathbf{R}^{\mathbf{2}}$ )}

Uji determinasi digunakan untuk menguji seberapa jauh kemampuan model dalam menerangkan variasi variabel dependen. Tabel 3 Berikut ini adalah ringkasan hasil uji $R^{2}$ menggunakan SPSS var 19.0:

Tabel 3. Hasil Uji Simultan Korelasi Variabel

\begin{tabular}{l|l|l|l|l}
\hline Model & $\mathbf{R}^{\mathbf{2}}$ & R. Square & Adj.R Square & Std Error \\
\hline 1 & 0,768 & 0,590 & 0,568 & 1,5406 \\
\hline
\end{tabular}

Sumber data: Diolah SPSS 19.0

Berdasarkan tabel 15 menunjukan bahwa koefisien determinasi ( $R$-squared $)=$ $0,590=59 \%$. Artinya, kemampuan variabel independen dalam menjelaskan perilaku variabel dependent sebesar 59 \% sedangkan sisanya sebesar $41 \%$ dijelaskan oleh variabel lain yang tidak dimasukan kedalam model.
Goodness on Fit Models yang ditunjukkan dengan Adj. R-squared menghasilkan koefisien sebesar $56,8 \%$ yang artinya perilaku atau variasi dari variabel independen Pemahaman Akuntansi dan Strategi Pemasaran dari variabel Dependen Keberhasilan UMKM sebesar $56,8 \%$ dan sisanya sebesar $43,2 \%$ 
adalah perilaku atau variasi dari variabel independen lain yang mempengaruhi Keberhasilan UMKM tetapi tidak dimasukan kedalam model. Walaupun nilai $\mathrm{R}$ square kecil tetapi jika melihat Adj. $R$ Square sebesar $56,8 \%$ maka secara umum model tersebut masih dapat digunakan.

\section{Pengaruh Pemahaman Akuntansi terhadap Keberhasilan UMKM}

Hasil penelitian menunjukan bahwa variabel Pemahaman Akuntansi memiliki koefisien regresi positif sebesar 0,376 dengan tingkat signifikansi 0,000 yaitu lebih kecil dari 0,05 . Penelitian ini membuktikan bahwa hipotesis 1 yang mengatakan terdapat pengaruh Pemahaman Akuntansi terhadap Keberhasilan UMKM adalah benar yaitu memiliki pengaruh signifikan positif. Penelitian ini menggunakan Quesioner list mengenai Pemahaman mengenai penerapan siklus akuntansi terhadap Keberhasilan UMKM, hasil penelitiannya mengatakan bahwa Pemahaman mengenai akuntansi berpengaruh terhadap Keberhasilan UMKM.

Hasil penelitian ini mendukung hasil penelitian Rini (2016) yang menunjukkan bahwa terdapat pengaruh yang signifikan antara pengalaman usaha terhadap keberhasilan usaha yang dimediasi oleh pemahaman informasi akuntansi, selain itu Wibowo \& Kurniawati (2016) mengemukakan bahwa penggunaan informasi akuntansi yang salah satunya adalah pemahaman akuntansi terbukti berpengaruh secara positif terhadap keberhasilan usaha pada UKM. Sedangkan Lohanda (2017) menunjukan bahwa terdapat pengaruh positif pemahaman akuntansi terhadap pelaporan keuangan berdasarkan SAK ETAP pada UMKM.

$\begin{array}{lrr}\text { Pemahaman Akuntansi diartikan } \\ \text { sebagai penguasaan seseorang } & \text { dalam } \\ \text { memahami proses akuntansi } & \text { sampai }\end{array}$
disusunnya laporan keuangan. Pemahaman akuntansi merupakan seseorang yang pandai dan mengerti benar tentang akuntansi, maksudnya seseorang dikatakan paham terhadap akuntansi adalah mengerti dan pandai bagaimana proses akuntansi itu dilakukan sampai menjadi suatu laporan keuangan dengan berpedoman prinsip dan standar penyusunan laporan keuangan. Pemahaman akuntansi dapat digunakan sebagai acuan dalam penyajian informasi keuangan yang berkualitas, jika seluruh pelaku usaha memiliki pemahaman akuntansi yang baik dalam menyusun informasi keuangan yang berkualitas pada usaha yang dijalankannya. Dengan adanya pemahaman akuntansi dari pelaku usaha UMKM di Kota Bogor, maka pelaku usaha akan mempengaruhi penyusunan informasi keuangan yang berkualitas dan akan menerapkan standar-standar akuntansi pada usaha yang dimiliki.

\section{Pengaruh Strategi Pemasaran Terhadap Keberhasilan UMKM \\ Variabel Strategi Pemasaran dalam} penelitian ini terbentuk dengan alat ukur adanya segmentasi pasar dan promosi terhadap produk terhadap Keberhasilan UMKM. Berdasarkan alat ukur tersebut maka dalam hasil penelitian menunjukan bahwa variabel Strategi Pemasaran memiliki koefisien regresi positif sebesar 0,199 dengan tingkat signifikansi 0,080 , yaitu lebih besar dari 0,05. Dengan korelasi hubungan terhadap Keberhasilan UMKM yaitu 0,199 (Kuat). Penelitian ini membuktikan bahwa HO dapat diterima atau secara parsial tidak terdapat pengaruh yang signifikan antara variabel strategi pemasaran terhadap Keberhasilan UMKM di Bogor.

Hasil penelitian ini tidak mendukung hasil penelitian Nursalina (2018) merek promosi berpengaruh terhadap keberhasilan usha mikro kecil berbasis ekonomi kreatif. Merk promosi merupakan bagian dari strategi pemasaran. Sedangkan Rangkuti dalam Saragi (2016) dalam penelitiannya menjelaskan bahwa unsur-unsur utama pemasaran dapat diklasifikasikan menjadi tiga unsur utama yaitu 
strategi persaingan, taktik pasar dan nilai pemasaran.

Hasil penelitian ini juga tidak mendukung penelitian dari Nandita et al. (2018) pemasaran kewirausahaan berpengaruh signifikan positif terhadap keberhasilan usaha. Berdasarkan observasi dan wawancara, pelaku usaha melakukan pemasaran produk dengan cara memanfaatkan jaringan dengan sesama pelaku usaha, informasi dari mulut ke mulut, dan menyesuaikan selera pasar. Meskipun hasil penelitian menyatakan bahwa Pemahaman Akuntansi berpengaruh positif terhadap Keberhasilan UMKM Bogor, akan tetapi Keberhasilan UMKM di Bogor masih belum bisa dikatakan baik karena banyak UMKM yang nyatanya hanya bertahan sebentar kemudian langsung tutup usaha karena mengalami kerugian, oleh karena itu selain pemahaman akuntansi diperlukan juga strategi pemasaran yang baik meskipun jenis usaha yang dinaungi merupakan produk kebutuhan sehari-hari.

\section{PENUTUP}

Berdasarkan pengujian yang telah dilakukan terhadap permasalahan yang dirumuskan dalam hipotesis penelitian dengan menggunakan regresi liner berganda, berdasarkan hasil analisis dan pembahasan maka dapat diambil kesimpulan bahwa Pemahaman Akuntansi berpengaruh terhadap Kelangsungan Usaha UMKM di Bogor dengan kesimpulan $\mathrm{H}_{1}$ diterima. Sedangkan Strategi pemasaran tidak berpengaruh terhadap Kelangsungan Usaha UMKM dengan kesimpulan $\mathrm{H}_{2}$ ditolak.

Pemahaman Akuntansi yang dimaksudkan dalam penelitian ini yaitu pandai dan mengerti benar tentang proses pencatatan transaksi secara sistematis mulai dari proses pencatatan berdasarkan bukti transaksi sampai dengan tahap pembuatan laporan keuangan. Hasil penelitian menunjukkan bahwa pemahaman akuntansi berpengaruh terhadap keberhasilan UMKM. $\mathrm{Hal}$ ini mengandung implikasi agar kedepannya pihak umkm meningkatkan pemahaman akuntansi untuk menopang keberhasilan umkm. Variabel Strategi Pemasaran dalam penelitian ini terbentuk dengan alat ukur adanya segmentasi pasar dan promosi terhadap produk terhadap Keberhasilan UMKM. Hasil penelitian menunjukkan bahwa strategi pemasaran tidak berpengaruh terhadap keberhasilan UMKM. Hal ini mengandung implikasi bahwa dalam menjalankan UMKM yang diperlukan adalah strategi pemasaran yang simple seperti door to door dan dari mulut ke mulut.

Penelitian ini dimasa mendatang diharapkan dapat menyajikan hasil penelitian yang lebih berkualitas lagi dengan adanya beberapa hal diantaranya: Penelitian selanjutnya disarankan untuk sampel pengisian kuesioner sebaiknya keseluruhan UMKM baik di Kota Bogor maupun di Kabupaten Bogor. Selain itu, menambah variabel-variabel lain yang lebih signifikan berpengaruh terhadap Keberhasilan UMKM seperti Pelatihan UMKM dan lain-lain.

\section{REFERENSI}

AL Smirat, B. Y. (2013). The Use of Accounting Information by Small and Medium Enterprises in South District of Jordan ,( An empirical study ). Research Journal of Finance and Accounting.

Arlianto, T. (2014). Pengaruh Penggunaan Informasi Akuntansi terhadap Keberhasilan UMKM (Studi Kasus pada Industri Konveksi Desa Padurenan Kecamatan Gebog Kabupaten Kudus). Universitas Kristen Satya Wacana Salatiga

Augustine, Yvonne Robert Kristaung. 2013. Metodologi penelitian bisnis dan akuntansi. Jakarta : Dian Rakyat

Ghozali, I. (2011). Aplikasi Analisis Multivariate Dengan Program IBM SPSS 19 (edisi kelima). In Aplikasi Analisis Multivariate 
dengan program SPSS. Semarang: Badan Penerbit Universitas Dipenogoro.

Lohanda, D. (2017). Pengaruh Tingkat Pendidikan, Pemahaman Akuntansi, Pelatihan Penyusunan Laporan Keuangan Terhadap Pelaporan Keuangan Umkm. Prodi Akuntansi UNY, 1, 1-20.

Nandita, B., Sarma, M., \& Najib, M. (2019). Faktor-Faktor yang Memengaruhi Keberhasilan Usaha UMKM Pengolahan Buah dan Pengolahan Susu. Jurnal Manajemen Dan Organisasi, 9(1), 1. https://doi.org/10.29244/jmo.v1i1.2534 2

Nursalina. (2018). Faktor-Faktor Yang Mempengaruhi Keberhasilan Usaha Mikro Kecil Berbasis Ekonomi Kreatif Di Kota Makassar. In Physical Review B.

Rini, Ayu Dwidyah. 2016. Relevansi Sikap dan Pengalaman Pelaku Usaha Mikro Kecil Menengah Pengusaha Muda dalam Pemahaman Akuntansi dan Pengaruhnya terhadap Keberhasilan Bisnis. Universitas Ciputra Surabaya

Sara, N. O. (2014). ANALISIS USAHA-USAHA PEMASARAN DALAM MENGHADAPI PERSAINGAN BISNIS USAHA KECIL MENENGAH. Jom FISIP.

Syarif, M. 2017. Kadiskop : Ada 23 Ribu UKM di Kota Bogor. Harian Ekonomi Neraca

Saragi, Adhe. 2016. Strategi Pengembangan Usaha Kecil Menengah Sektor Industri Kerajinan Batu Bata Berdasarkan
Analisis SWOT. Yogyakarta : Universitas Sanata Dharma.

Sugiyono. 2013. Statistika untuk Penelitian. Bandung : Alfabeta

Sitohang, Sonang. 2011. Faktor-faktor yang mempengaruhi keberhasilan Usaha Kecil Menengah (UKM). Jember : Universitas Jember

Warcito, W., \& Saleh, A. (2016). Strategi Pengembangan Usaha Mikro dan Kecil Pada Usaha Pengolahan Pangan. Jurnal Manajemen.

https://doi.org/10.32832/jmuika.v7i2.1113

Wibowo, A., \& Kurniawati, E. P. (2016). Pengaruh Penggunaan Informasi Akuntansi Terhadap Keberhasilan Usaha Kecil Menengah (Studi Pada Sentra Konveksi di Kecamatan Tingkir Kota Salatiga). Jurnal Ekonomi Dan Bisnis, 18(2), 107. https://doi.org/10.24914/jeb.v18i2.269

Wilfa, Razannisa; Sagoro, E. M. (2016). Pengaruh Persepsi Terhadap Laporan Keuangan dan Pemahaman Akuntansi Terhadap Kualitas Laporan Keuangan UMKM. Jurnal Akuntansi Universitas Negeri Yogyakarta.

Yusri, M. Bustari.2014. Strategi Pemasaran dan Pengaruhnya Terhadap Perkembangan Usaha UMKM Makanan Ringan di Kota Payakumbuh Sumatera Barat. Seminar Nasional Riset Inovatif II ISSN. 23391553. 